\title{
Impact and Consequences of COVID-19 on Criminal Proceedings in the Russian Federation
}

\author{
Dneprovskaya M.A. ${ }^{*}$ Kalandarishvili Kh.A. ${ }^{2}$ Nepomnyashchikh L.A. ${ }^{3}$ \\ ${ }^{1}$ Institute of Economics, Management and Law, Irkutsk National Research Technical University, Irkutsk 664074, Russia \\ ${ }^{2}$ The East-Siberian Branch Russian State University of Justice, Irkutsk 664074 Russia \\ ${ }^{3}$ Bar Chamber of the Irkutsk Region, Irkutsk 664047 Russia \\ *Corresponding author. Email: mariosky@ rambler.ru
}

\begin{abstract}
In the present study, the authors draw attention to the impact and consequences of the COVID-19 pandemic on criminal proceedings. The authors consider what consequences the pandemic had on the work of the courts, the investigation officers, as well as the authorities executing the court decision on the detention of accused persons. Among the unfavourable consequences, which influenced the criminal proceedings, are the violation of the accused's right to attorney; the impossibility to provide the accused with qualified legal assistance due to the self-isolation of lawyers and quarantine measures prohibiting their entry into the pretrial detention centers; the refusal of investigation officers to postpone the investigative actions because of lawyer's default due to self-isolation; postponement of court proceedings and the extension of the term of the criminal trials and others. The authors suggest ways to solve the problem in case of recurrent situation, in particular, they propose to provide for provisions at the legislative level to regulate criminal proceedings in the conditions of pandemic, noting a multifaceted approach to solving the problem in order to balance the rights and legitimate interests of the accused and to comply with the norms of criminal procedure legislation. It is necessary to change the attitude towards the pretrial detention as a preventive measure and choose other alternative preventive measures in the context of a pandemic in order to unload the pretrial detention centers and protect the health of both the employees of the pretrial detention center and the persons detained there. Besides, it is necessary to convert criminal proceedings into electronic format and implement modern digital technologies, which allow to limit communication between participants of criminal proceedings as much as possible and provide exchange of procedural documents within the framework of electronic document circulation.
\end{abstract}

Keywords: pandemic justice, investigation, preventive measures, digital technologies

\section{INTRODUCTION}

The modern world, including Russia, faced the COVID-19 pandemic, which paused all activities. Occurring events in the world, forced quarantine and official holidays, taken as measures aimed at prevention of coronavirus spreading, influenced the work of authorities, carrying out pretrial investigation and sentence-implementation services, and courts, and criminal proceedings in general. Russia was not ready for such a situation and various measures were taken to prevent violations of the rights of participants in criminal proceedings, to ensure compliance with deadlines, taking into account the public nature of criminal proceedings related to coercion, in particular the use of preventive measures.

\section{RESEARCH METHODS}

The research methods are general scientific (systematic, logical) and private scientific (formal and legal).

\section{RESULTS AND DISCUSSION}

Coronavirus infection, which spread around the world, influenced the work of law enforcement and judicial systems, the crime situation in different countries, and became the "number 1 " theme in the research of scientists [1-6]. In connection with the spread of coronavirus infection, operational activities and recommendations were needed to prevent it.

In regions and cities across Russia, state officials are taking extraordinary measures to limit people's movements and curb the spread of coronavirus. [7].

Since March 2020, due to the threat of coronavirus infection (2019-nCoV) spreading in the Russian Federation, all participants of criminal proceedings were 
exposed to the risk of infection. By the Resolution of the Presidium of the Supreme Court of the Russian Federation, Presidium of the Council of Judges of the Russian Federation of March 18, 2020 in the period from March 19 to April 10, 2020 it was recommended to suspend personal reception of citizens in courts and to accept documents through electronic internet-receiving offices of courts or by mail of Russia; to consider only categories of pressing matter (on applying, prolongation, vacating or change of measure of restraint, on the protection of the interests of a minor or a person recognized as legally incompetent, in the event of refusal of the legal representative from medical intervention necessary to save life, and others), all courts, if technically possible, to initiate consideration of cases by using videoconferencing systems; to restrict access to courts of persons who are not participants in legal proceedings [8]. At the same time, the work of the courts within the conditions of the pandemic was not perfect. Despite the fact that most of the courts during the pandemic considered pressing matters, nevertheless, there was an inappropriate organization of their consideration. Sessions of the court began with delays. Antiepidemiological measures to maintain social distancing were not followed. There was also improper procedural communication with the participants of the process, notices of sessions of the court were often untimely and inappropriate. It should be separately noted the limitations in familiarization with the materials of criminal cases before the start of session of the court. In most cases, lawyers were allowed into the courtroom together with investigators who filed petitions with the court to apply or prolong a measure of restraint immediately before the start of the trial, which led to the impossibility of timely familiarization with the materials and coordination of positions with the defendants. Or a very limited time was given before the session of the court, which resulted in the impossibility to prepare well-reasoned written petitions and statements.

A number of issues arising from the calculation of procedural periods, the applying adequate measures of restraint, the conduct of investigative actions, and others during the pandemic were resolved by the Presidium of the Supreme Court of the Russian Federation on April 21, 2020 in the Review of certain issues of judicial practice related to the application of legislation and measures to counter the spread of a new coronavirus infection (COVID-19) № 1 in the Russian Federation [9].

The impossibility of considering the case in connection with the introduction of measures to counter the spread of a new coronavirus infection (COVID-19) in the territory of the Russian Federation may be grounds for postponement of court proceedings by virtue of part 1 of Article 253 of the Criminal Procedure Code of the Russian Federation. Most sessions of the court were postponed due to the failure of the parties to appear for valid reasons. There have been cases of postponing the date of consideration of a criminal case on the merits with the wording "in connection with the threat of the spread of coronavirus infection". In a number of situations, cases were considered without any participation of the accused (defendants). At the same time, the courts referred to the documents of the Federal Penitentiary Service about the impossibility of bringing the accused to court [10].

The usual regime of criminal proceedings with the legally provided procedural periods and the implementation of the necessary procedural actions turned out to be difficult. A guideline for officials conducting preliminary investigations during the pandemic was adherence to procedural periods in conducting investigative activities, often neglecting public health care. The investigator was forced to carry out the investigative action in order not to violate the terms of the preliminary investigation at the risk of infection of himself and the participants of the criminal proceedings.

Only in the case of infection of the accused with coronavirus, the investigator should have suspended the preliminary investigation in accordance with paragraph 4 of paragraph 1 of Article 208 of Criminal Procedure Code of the Russian Federation, according to which the preliminary investigation is suspended in the case of temporary serious illness of the suspect or accused, certified by a medical report that prevents his participation in the investigation and other procedural actions.

Introduction of a regime of self-isolation and quarantine has affected the possibility of appearance of persons obliged to observe the established restrictions, to participate in procedural actions. The right of a lawyer to refuse to participate in investigative actions in conditions that threaten to infect him/her is not enshrined in the law and is currently regarded as a refusal to perform professional duties, which leads to disciplinary responsibility. Investigators often refused to grant defense motions to postpone the investigation because of the threat of the spread of coronavirus. Kachalova O.V. substantiates the position that in such cases the advocacy has the right to file a complaint with the court in accordance with Article 125 of the Criminal Procedure Code of the Russian Federation [11].

A serious problem of criminal proceedings in Russia is the frequent use of pretrial detention as a preventive measure in the investigation of crimes. This was stated by the High Commissioner for Human Rights in the Russian Federation Tatyana Nikolaevna Moskalkova in November 2016, who argued that for people who do not pose a risk to the public, recognizance not to leave or house arrest is enough preventive measure [12].

The problem worsened during the pandemic. Human rights defenders in Russia have been calling for a general amnesty, in order to reduce the burden on pretrial detention centers during the coronavirus pandemic [13]. The Head of the Federal Penitentiary Service of the Russian Federation expressed his concern about overcrowding in pretrial detention centers and the risk of infection due to the high density of persons kept in pretrial detention centers and correctional institutions and asked the Chairman of the Supreme Court of the Russian Federation to refuse to arrest people for crimes of small and medium gravity during the coronavirus pandemic [14]. According to Kvyk A. V. the risk of spreading infection should be mentioned as one of the grounds for applying a 
preventive measure other than detention, suggesting more active use of prohibitions on certain actions, bail with the establishment of prohibitive measures, and house arrest [15].

In connection with the risk of mass infection of persons held in places of compulsory isolation and the spread of infection, the legal community proposed to use the fact of sanitary-epidemiological danger as one of the arguments for the application of a milder preventive measure, not related to detention in the pretrial detention center, when deciding on the choice of preventive measure. However, the provisions of the acts adopted in connection with the pandemic, confirming its existence and the danger to the life and health of citizens, were not properly taken into account by the judges and were not applied when justifying the use of milder forms of preventive measure. Subsequently, this justification for the choice of a preventive measure was recommended for use in judicial practice by the court and was reflected in the Review on certain issues of judicial practice related to the application of legislation and measures to counter the spread of a new coronavirus infection on the territory of the Russian Federation, approved by the Presidium of the Supreme Court of the Russian Federation on April 30. 2020 [16].

At the peak of the pandemic, the provision of long and short visits was suspended in the institutions of the territorial bodies of the Federal Penitentiary Service of the Russian Federation and the pretrial detention centers of the Federal Penitentiary Service of the Russian Federation [17].

The prohibition on admission of lawyers to persons in detention became an insurmountable obstacle in forming an agreed position with defendants in a criminal case, effectively leaving them without legal assistance. Visits to pretrial detention centers were possible only together with investigators, which was a violation of the right to defense of persons held in the pretrial detention center, because the accused and the criminal defence lawyer have the right to have a private and confidential meeting with each other, without limiting their number and duration.

Like many citizens of the Russian Federation, lawyers have isolated themselves during the COVID-19 coronavirus pandemic, exercising their professional function through information and telecommunications network "Internet". At the same time, participation in investigative activities through remote information and digital technologies was often not used. And even if it was used, the quality of audibility and visibility in some cases was low. A number of questions, such as: whether selfisolation of a lawyer is grounds for extending the appeal period; how to familiarize yourself with the case and file a complaint on time if the person is in a category that is not recommended (or prohibited) to leave the house at all, and others require permission. The quarantine measures introduced in Russia have revealed many unexplained tasks in the judicial system and law enforcement agencies, but it was the closure of courts that most significantly limited the right of lawyers to work [18].

The resulting pandemic requires the active introduction of digital technologies in criminal proceedings, the transition to the use of modern digital technologies, the conversion of a criminal case into an electronic format, communication through electronic document management, the use of an e-judge in the preparation of court decisions [19-23].

Law enforcement activities in the criminal proceeding system cannot be completely suspended even in a state of emergency or a pandemic. Life and health is a fundamental inalienable constitutional human right, as well as the right to judicial protection and legal assistance. In the context of the spread of infections, in any case, the expediency and possibility of judicial and investigative activities must be balanced in terms of different constitutional values. The rights and interests of participants in criminal proceedings, be it an accused, a lawyer, an investigator, a judge, must be respected not only from the standpoint of compliance with the norms of criminal procedure legislation, but also from the standpoint of protecting human values, since these are people who may be exposed to coronavirus infection

\section{CONCLUSION}

The modern legal and law enforcement system was not ready for safe functioning in the current unfavourable epidemiological situation, but the prompt measures to the situation allowed to mitigate the possible dangerous effects of the spread of the pandemic along with violation of some rights. The regime of restrictions due to coronavirus was introduced spontaneously and unexpectedly for the work of the legal system, law enforcement agencies and all those involved in criminal proceedings. To be prepared for such situations, it is necessary to use a combination of law enforcement, legislative and organizational tools. It is necessary at the interdepartmental level of organizations and institutions involved in criminal proceedings, to adopt joint normative acts that would regulate their activities in such a situation. It is necessary to make additions to the Criminal Procedure Code of the Russian Federation and to entrench the rules of criminal proceedings in such and similar emergency conditions that threaten life and health. Do not use pretrial detention of suspects (accused), if the circumstances of the criminal case allow, but apply other alternative preventive measures, such as prohibition of certain actions, house arrest, in order to reduce the risk of the spread of infection in places of detention. In addition, the criminal procedure law should provide for the threat of spreading a coronavirus or similar infection as a basis for suspension, postponement of judicial and investigative actions in the context of a pandemic. The concept of "categories of pressing matters", which should be considered first, should be more clearly defined. It is necessary to provide the court with video-conferencing systems and other digital technologies that allow to limit the face-to-face communication of participants of criminal proceedings as much as possible; providing the exchange of procedural documents. 


\section{REFERENCES}

[1] J.M. Baldwin, J.M. Eassey, E.J. Brooke, Court Operations during the COVID-19 Pandemic, American journal of criminal justice 45(4) (2020) 743-758. DOI: 10.1007/s12103-020-09553-1

[2] T. Sourdin, J. Zeleznikow, Courts, Mediation and COVID-19, Australian business law review 48(2) (2020) 138-158.

[3] T. Hodgkinson, M.A. Andresen, Show me a man or a woman alone and I'll show you a saint: Changes in the frequency of criminal incidents during the COVID-19 pandemic, Journal of Criminal Justice 69 (2020). DOI: 10.1016/j.jcrimjus.2020.101706

[4] S.I. Beia, M. Bran, I. Petrescu, V.E. Beia, M. Dinu, Food fraud incidents: findings from the latest rapid alert system for food and feed (rasff) report, Tific papersseries management economic engineering in agriculture and rural development 2 (2020) 45-52.

[5] H. Gordilho, E. Gondim, The crime of violating health emergency rule during a pandemic in Brazil, Cadernos de dereito actual 13 (2020) 70-79.

[6] J.M. Miller, A. Blumstein, Crime, Justice \& the COVID-19 Pandemic: Toward a National Research Agenda, American journal of criminal justice 45(4) (2020) 515-524.

[7] Pandemic Justice: How COVID-19 and coronavirus containment measures have exacerbated problems in Russia's courts and prisons. 2020. Retrieved from https://meduza.io/en/episodes/2020/04/17/pandemicjustice-how-covid-19-and-coronavirus-containmentmeasures-have-exacerbated-problems-in-russia-scourts-and-prisons

[8] The Resolution of the Presidium of the Supreme Court of the Russian Federation, of March 18, 2020. 2020. Retrieved from https://vsrf.ru/press_center/news/28815/

[9] The Review of certain issues of judicial practice related to the application of legislation and measures to counter the spread of a new coronavirus infection (COVID-19) № 1 in the Russian Federation, passed by the Presidium of the Supreme Court of the Russian Federation on April 21, 2020. 2020. Retrieved from http://base.garant.ru/73924465/\#friends

[10] O.I. Andreeva, O. V. Kachalova, Russian criminal trial in the era of coronavirus: challenges of time,
Tomsk State University Journal 36 (2020) 5-15. DOI: $10.17223 / 22253513 / 36 / 1$

[11] O.V. Kachalova, Coronavirus as a basis for a complaint under article 125 of the CCP. 2020.

Retrieved from https://www.ugpr.ru/article/1859koronavirus-kak-osnovanie-dlya-jaloby-po-state-125upk

[12] T. N. Moskalkova, Vicious circle of Themis. 2016. Retrieved from https://iz.ru/news/645435

[13] Russian Supreme Court advises against jailing people accused of minor offenses due to COVID-19 pandemic. 2020. Retrieved from https://meduza.io/en/news/2020/04/30/russian-supremecourt-advises-against-jailing-people-accused-of-minoroffenses-due-to-covid-19-pandemic

[14] Federal Penitentiary Service asked not to arrest for minor offences because of the virus. 2020. Retrieved from

https://www.rbc.ru/society/18/04/2020/5e9ae92c9a7947 7104514365

[15] A.V. Kvyk, The COVID-19 pandemic as a reason for choosing preventive measures alternative to detention. 2020. Retrieved from https://e.ugpr.ru/821006

[16] The Review of certain issues of judicial practice related to the application of legislation and measures to counter the spread of a new coronavirus infection (COVID-19) № 1 in the Russian Federation, passed by the Presidium of the Supreme Court of the Russian Federation on April 30, 2020. 2020. Retrieved from https://base.garant.ru/73972665/

[17] The Federal Penitentiary Service of the Russian Federation reports. 2020. Retrieved from http://fsin.gov.ru/news/index.php?ELEMENT_ID=502 612

[18] A. Kupriianov, Coronavirus and "loopholes" in criminal proceeding. 2020. Retrieved from https://www.ugpr.ru/article/1848-koronavirus-iprobely-v-ugolovnom-protsesse

[19] O.V. Kachalova, Yu.A. Tsvetkov Electronic Criminal Case as a Tool for Development of Criminal Proceedings, Russian Justice 2 (2015) 95-101.

[20] E.V. Markovicheva, Prospects for Introduction of Elements of e-Justice in the Russian Criminal Proceedings, Russian Justice 3 (2017) 88-95. 
[21] A.S. Aleksandrov, O.I. Andreeva, O.A. Zaytsev, On Development Prospects of the Russian Criminal Proceeding in the Context of Digitalization, Tomsk State University Journal 448(2019) 199-208. DOI: $10.17223 / 15617793 / 448 / 25$

[22] M.A. Dneprovskaya, S.A. Abramitov, Digital Technologies in Activities of Russian Courts: Prospects of Artificial Intelligence Application Retrieved. 2020. Retrieved from https://doi.org/10.2991/aebmr.k.200502.034

[23] O.I. Andreeva, V.V. Ivanov, A.Yu. Nesterov, T.V. Trubnikova, Facial Recognition Technologies in Criminal Proceedings: Problems of Grounds for the Legal Regulation of Using Artificial Intelligence, Tomsk State University Journal 449 (2019) 201-212. DOI: https://doi.org/10.17223/15617793/449/25 